\title{
World Journal of Emergency

Review

\section{Penetrating injury to the chest by an attenuated energy projectile: a case report and literature review of thoracic injuries caused by "less-lethal" munitions \\ Joao Rezende-Neto*1,2,3, Fabriccio DF Silva ${ }^{1}$, Leonardo BO Porto ${ }^{1}$, Luiz C Teixeira ${ }^{1}$, Homer Tien ${ }^{3}$ and Sandro B Rizoli ${ }^{3}$}

Address: ${ }^{1}$ Risoleta Tolentino Neves University Hospital Trauma Center - Universidade Federal de Minas Gerais, Belo Horizonte, Brazil, ${ }^{2}$ Coordenacao de Aperfeicoamento de Pessoal de Nivel Superior (CAPES), Esplanada dos Ministérios Bloco "L" - Anexo II $2^{\circ}$ andar, Brasilia, Brazil and ${ }^{3}$ Sunnybrook Health Sciences Centre, University of Toronto, Toronto, Canada

Email: Joao Rezende-Neto* - ljrezende@yahoo.com.br; Fabriccio DF Silva - fdoreafsilva@hotmail.com; Leonardo BO Porto - jbop@uai.com.br; Luiz C Teixeira - fe_teixeira@terra.com.br; Homer Tien - homer.tien@sunnybrook.ca; Sandro B Rizoli - sandro.rizoli@sunnybrook.ca

* Corresponding author

Published: 26 June 2009

World Journal of Emergency Surgery 2009, 4:26 doi:10.1 186/1749-7922-4-26

This article is available from: http://www.wjes.org/content/4/I/26

(c) 2009 Rezende-Neto et al; licensee BioMed Central Ltd.

This is an Open Access article distributed under the terms of the Creative Commons Attribution License (http://creativecommons.org/licenses/by/2.0), which permits unrestricted use, distribution, and reproduction in any medium, provided the original work is properly cited.
Received: 18 March 2009

Accepted: 26 June 2009

\begin{abstract}
We present the case of a patient who sustained a penetrating injury to the chest caused by an attenuated energy rubber bullet and review the literature on thoracic injuries caused by plastic and rubber "less-lethal" munitions. The patient of this report underwent a right thoracotomy to extract the projectile as well as a wedge resection of the injured lung parenchyma. This case demonstrates that even supposedly safe riot control munition fired at close range, at the torso, can provoke serious injury. Therefore a thorough investigation and close clinical supervision are justified.
\end{abstract}

\section{Background}

Currently, crowd control is ideally enforced by a trained police force using "less-lethal" tactics and weapons. Previous reports of serious injuries and even deaths, caused by hard rubber bullets, have prompted the development of safer, attenuated energy rounds [1-3]. Examples include the plastic baton rounds and the more recent attenuated energy projectile. These rounds represent safer options than the original rubber bullets and are currently used by many different police forces.

We report a rare case of a penetrating injury to the chest caused by an attenuated energy projectile. We then review the historical development and injury literature surrounding rubber and plastic "less-lethal" impact munitions.

\section{Case presentation}

A 24-year-old male was shot in the right hemithorax by an attenuated energy projectile (AEP), fired from a 12-gauge shotgun at close range (less than $3 \mathrm{~m}$ ). He arrived to our Trauma Center approximately 36 hours after the injury. He presented with a fever, had decreased breath sounds on the right side, and his vital signs were stable (pulse was 100 , blood pressure was $140 / 90 \mathrm{mmHg}$. Physical examination revealed a single skin laceration $(2.0 \mathrm{~cm})$ with surrounding contusion at the right mid-axillary line; $4^{\text {th }}$ intercostal space. The admission chest radiograph revealed a small right pneumothorax, pulmonary contusion and radiopaque material within the right middle lobe (Figure 1). A right-sided thoracostomy tube drained minimal air and blood. A computed tomography (CT) 

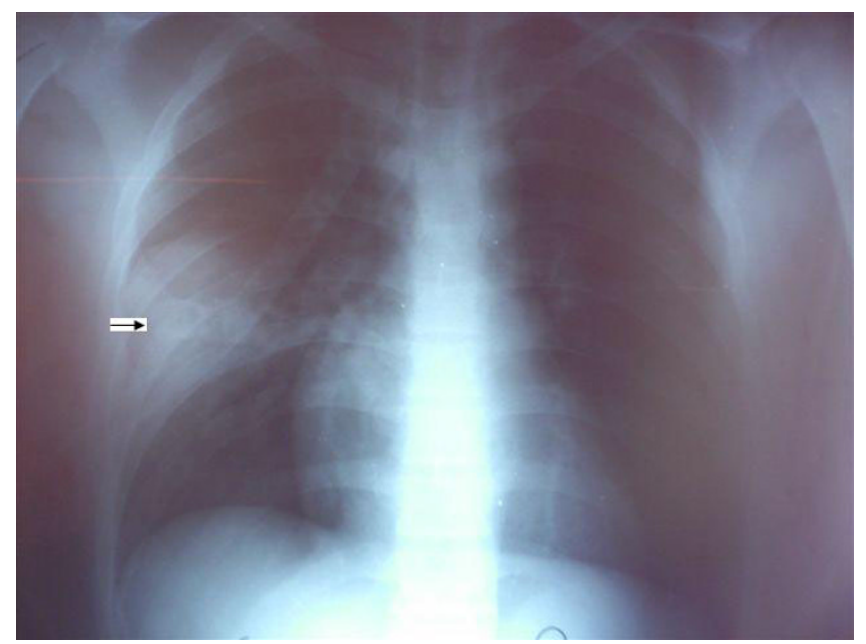

\section{Figure I}

Admission chest radiography. Admission chest radiograph shows a radiopaque image within a pulmonary contusion (arrow), and a small pneumothorax on the right hemithorax.

scan of the chest demonstrated a foreign body in the right hemithorax with the form of an AM-403/P attenuated energy projectile (Figure 2). Due to septic complications and the size of the foreign body, the patient underwent a right thoracotomy which revealed a $19 \mathrm{~g}(6.5 \times 2.5 \mathrm{~cm})$ projectile within the middle lobe, which was surrounded by an intra-parenchymal hematoma (Figure 3 ). The projectile and injured parenchyma were removed by wedge resection. The patient had an uneventful hospital stay and was discharged home 5 days later.

\section{Discussion}

"Less-lethal" weapons are explicitly designed and primarily employed to incapacitate personnel, while minimiz-

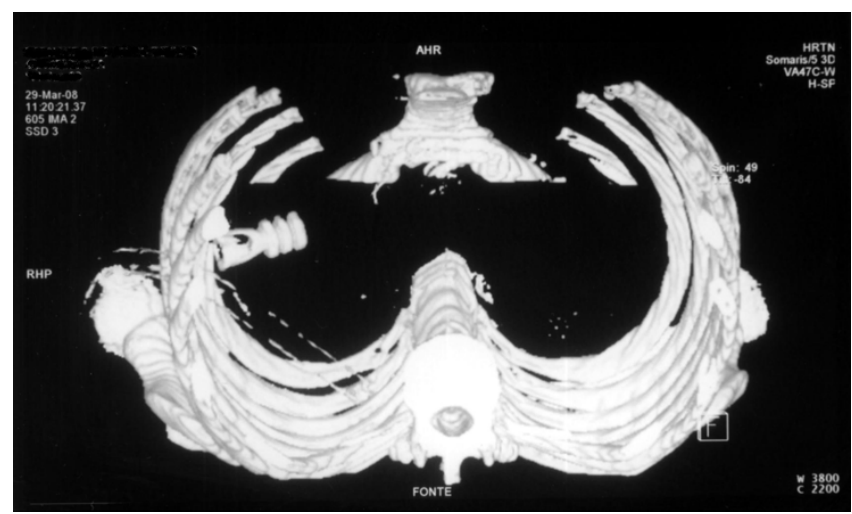

Figure 2

Admission CT scan of the chest. CT three-dimensional (3D) image reconstruction of the chest shows an intra-thoracic attenuated energy projectile and a chest thoracostomy tube inside the right hemithorax.

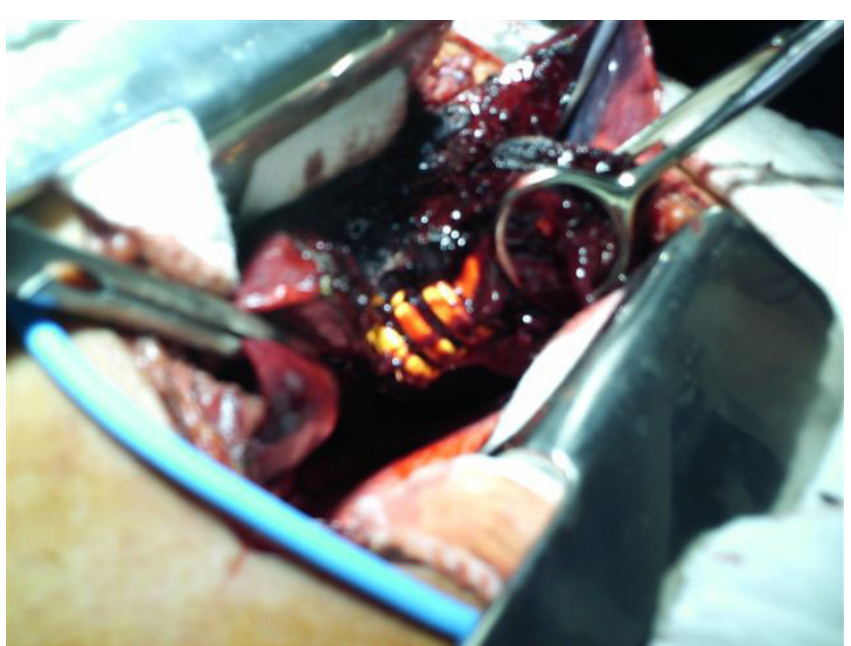

Figure 3

Intra-operative finding. Intra-operative photograph depicts the AM-403/P attenuated energy projectile within the lung parenchyma during wedge resection.

ing fatalities [4]. There are many classes of "less lethal weapons" including conducted electrical weapons (commonly referred to as a TASER), chemical irritants (Pepper spray), and impact munitions. Impact munitions include "bean bag rounds", rubber bullets, plastic baton rounds, and attenuated energy projectile. As our case is an example of a serious injury caused by a rubber bullet, we focused our literature review on chest injuries caused by rubber and plastic "less lethal" munitions from 1972 to 2008 (Table 1).

When a projectile strikes a person, its kinetic energy at impact is defined by its mass and its velocity $(1 / 2 \times$ mass $\times$ velocity $\left.{ }^{2}\right)$. Ballistic studies suggest that a projectile needs to apply a "threshold energy density" of greater than $0.1 \mathrm{~J} /$ $\mathrm{mm}^{2}$ to skin in order to penetrate and cause internal injuries [5]. Manufacturers of rubber bullets modify the composition (mass: rubber vs lead), ballistic properties (velocity) and size (cross-sectional area) in order to reduce the likelihood of skin penetration. Furthermore, law-enforcement officers often have specific "rules of engagement" for using these types of munitions that further reduce the likelihood of penetration and serious injury; such rules include firing at distances over 40 meters and changing the point of aim to body regions where skin has increased elastic properties (lower anterior abdomen or thigh) to allow the energy to dissipate over a larger cross-sectional area [6].

One broad classification of "less lethal" impact munitions is direct versus indirect fire rounds. Indirect fire munitions are made of relatively dense material, and are therefore fired in front of targets with the purpose of "skipping" them into targets. Accuracy, however, is lost and the 
Table I: Articles published in the English language pertaining to thoracic injuries caused by rubber and plastic "less-lethal" impact munitions (1972-2009)

\begin{tabular}{|c|c|c|c|c|c|c|}
\hline Author/Year & $\begin{array}{c}\text { Bullet Type/Speed/ } \\
\text { Energy }\end{array}$ & $\begin{array}{l}\text { Range } \\
(\mathrm{m})\end{array}$ & Total Cases/Chest & $\begin{array}{l}\text { Intra-thoracic } \\
\text { Penetration }\end{array}$ & $\begin{array}{c}\text { Significant thoracic } \\
\text { injuries }\end{array}$ & Outcome \\
\hline $\begin{array}{l}\text { Shaw J. } \\
1972\end{array}$ & $\begin{array}{l}\text { Rubber } \\
150 \mathrm{~g} / \\
116.5 \mathrm{~m} / \mathrm{s} /\end{array}$ & 27.4 & $3^{\wedge}$ & No & Lung contusion (3) & All survived \\
\hline $\begin{array}{l}\text { Millar R. } \\
1975\end{array}$ & $\begin{array}{c}\text { Rubber } \\
140 \mathrm{~g} / 73 \mathrm{~m} / \mathrm{s} / *\end{array}$ & $*$ & $90 / 18$ & No & $\begin{array}{l}\text { Lung contusion(5), } \\
\text { pneumothorax }(I) \text {, rib } \\
\text { fracture }(2)\end{array}$ & All survived \\
\hline $\begin{array}{c}\text { Sheridan S. } \\
1983\end{array}$ & Plastic $135 \mathrm{~g} / * / *$ & $*$ & $|47 / 2|$ & $*$ & $*$ & $*$ \\
\hline $\begin{array}{c}\text { Rocke L. } \\
1983\end{array}$ & Plastic/*/* & $*$ & $99 / 10$ & No & $\begin{array}{l}\text { Lung contusion(7), } \\
\text { rib fracture(I) }\end{array}$ & All survived \\
\hline $\begin{array}{l}\text { Ritchie A. } \\
\text { 1990;1992 }\end{array}$ & Plastic $134.5 \mathrm{~g} / 69.4 \mathrm{~m} / \mathrm{s}$ & $*$ & $123 / 70$ & Yes & $\begin{array}{l}\text { Lung contusion, } \\
\text { hemo-pneumothorax, } \\
\text { rib fracture, } \\
\text { sternum fracture, } \\
\text { myocardial contusion, } \\
\text { cardiac tamponade. }\end{array}$ & 5 Deaths \\
\hline $\begin{array}{c}\text { Walden R. } \\
1990\end{array}$ & Plastic/* & $*$ & $1 / 1$ & Yes & Arterial embolization. & Survived \\
\hline Missliwetz J. I99 I & $\begin{array}{c}\text { Plastic pellets I } \mathrm{g} / 302 \\
\mathrm{~m} / \mathrm{s} / \\
694 \mathrm{~J}\end{array}$ & 4.5 & $4 / 1$ & Yes & Soft tissue injury & Survived \\
\hline $\begin{array}{l}\text { Yellin A. } \\
1992\end{array}$ & Plastic $8.5 \mathrm{~g} / * / *$ & $*$ & $26 / 26^{\circ}$ & Yes & $\begin{array}{l}\text { Lung contusion (18) rib } \\
\text { fracture }(8), \text { hemo- } \\
\text { pneumothorax }(6), \\
\text { cardiac injury }(3) \text { sternal } \\
\text { fracture }(1) \text {, scapula } \\
\text { fracture }(1) \text {, vascular } \\
\text { injury (5), esophageal } \\
\text { injury (I) }\end{array}$ & I Death \\
\hline $\begin{array}{l}\text { Hiss J. } \\
1997\end{array}$ & $\begin{array}{c}\text { Rubber and steel//5.4 g/ } \\
100 \mathrm{~m} / \mathrm{s} / 41.5 \mathrm{~J} \text { and } \\
\text { Plastic } 0.85 \mathrm{~g} / 1225 \mathrm{~m} / \mathrm{s} / \\
663.7 \mathrm{~J}\end{array}$ & $*$ & $17 / 2$ & Yes & $\begin{array}{l}\text { Lung and heart } \\
\text { lacerations }\end{array}$ & 2 Deaths \\
\hline $\begin{array}{l}\text { Voiglio E.J } \\
\quad 1998\end{array}$ & Rubber pellets/*/* & Contact & $1 / 1$ & Yes & $\begin{array}{l}\text { Hemothorax, rib fracture, } \\
\text { cardiac laceration. }\end{array}$ & Died \\
\hline $\begin{array}{l}\text { Chute DJ } \\
1998\end{array}$ & $\begin{array}{l}\text { Plastic } 79.4 \mathrm{~g} / 74 \mathrm{~m} / \mathrm{s} / \\
220 \mathrm{~J}\end{array}$ & $*$ & $1 / 1$ & No & $\begin{array}{c}\text { Hemothorax, rib fracture, } \\
\text { lung laceration, cardiac } \\
\text { laceration }\end{array}$ & Died \\
\hline $\begin{array}{c}\text { Steele J.A } \\
\quad 1999\end{array}$ & $\begin{array}{c}\text { Plastic } \\
135 \mathrm{~g} / 70 \mathrm{~m} / \mathrm{s} / 332 \mathrm{~J}\end{array}$ & * & $155 / 25$ & $*$ & $*$ & All survived \\
\hline $\begin{array}{l}\text { Mahajna A. } \\
2002\end{array}$ & $\begin{array}{l}\text { Rubber } \\
48 \mathrm{~g} / 130 \mathrm{~m} / \mathrm{s} / 46 \mathrm{~J} \text { and } \\
17 \mathrm{~g} / 78 \mathrm{~m} / \mathrm{s} / 33 \mathrm{~J}\end{array}$ & $30-80$ & $152 / 39$ & Yes & $\begin{array}{l}\text { Lung contusion and rib } \\
\text { fracture }(8), \\
\text { pneumothorax (6), } \\
\text { hemothorax (4), cardiac } \\
\text { tamponade (I), cardiac } \\
\text { contusion (I), vascular } \\
\text { injury (I) }\end{array}$ & All survived \\
\hline $\begin{array}{l}\text { Kalebi A. } \\
2005\end{array}$ & Rubber pellets $* / * / *$ & $*$ & $1 / 1$ & Yes & $\begin{array}{l}\text { Hemothorax, lung } \\
\text { laceration, rib fracture }\end{array}$ & Died \\
\hline $\begin{array}{l}\text { Hughes D. } \\
2005\end{array}$ & Plastic $98 \mathrm{~g} / 64 \mathrm{~m} / \mathrm{s} / 244 \mathrm{~J}$ & $*$ & $28 / 7$ & No & Lung contusion & All survived \\
\hline $\begin{array}{c}\text { Wahl P. } \\
2006\end{array}$ & Rubber $28 \mathrm{~g} / * / 200 \mathrm{~J}$ & 2 & $2 / 1$ & No & $\begin{array}{l}\text { Lung contusion, cardiac } \\
\text { contusion }\end{array}$ & Survived \\
\hline Maguire K. 2007 & $\begin{array}{l}\text { Plastic attenuated } \\
\text { energy } 28 \mathrm{~g} / * / 200 \mathrm{~J}\end{array}$ & $*$ & $13 / 2$ & No & Pneumothorax (I) & Survived \\
\hline Chowaniec C. 2008 & $\begin{array}{c}\text { Rubber } 8 \mathrm{~g} / 94 \mathrm{~m} / \mathrm{s} / 40 \mathrm{~J} \\
\text { and pellets } 0.3 \mathrm{~g} / 215 \mathrm{~m} / \\
\mathrm{s} / 7.3 \mathrm{~J}\end{array}$ & $*$ & $1 / 1$ & Yes & $\begin{array}{l}\text { Hemothorax, lung } \\
\text { laceration, cardiac } \\
\text { laceration }\end{array}$ & Died \\
\hline $\begin{array}{c}\text { Rezende-Neto J. } \\
2009\end{array}$ & $\begin{array}{l}\text { Rubber attenuated } \\
\text { energy } 19 \mathrm{~g} / 130 \mathrm{~m} / \mathrm{s} / \\
200 \mathrm{~J}\end{array}$ & 2 & $\mathrm{I} / \mathrm{I}$ & Yes & $\begin{array}{l}\text { Pneumothorax, lung } \\
\text { laceration }\end{array}$ & Survived \\
\hline
\end{tabular}

Range in meters; * Missing information; ^children; ’ only patients with penetrating chest injuries were included in the study. 
chance of hitting "non-elastic" structures such as the head and the chest increases, and therefore, causing greater risk of serious injury or death [7].

Direct-fire rubber bullets were used for the first time by British Forces in Northern Ireland in 1970 [8]. These bullets were also relatively inaccurate, as such, many injuries and even some deaths were associated with their use $[3,8,9]$. Children, teenagers, and women who are of a smaller built were reported to sustain severe injuries more often than larger individuals, particularly to the skull, eyes, brain, lungs liver, and spleen. [3,9-11]. That is in keeping with the results of a previous study, performed on unembalmed cadavers, that demonstrated greater injury risk of blunt ballistic impacts in $5^{\text {th }}$ percentile female patients - abbreviated injury severity score chest (AISchest 1 ) - compared to $50^{\text {th }}$ percentile males (AIS-chest 2) struck by a 12-gauge rubber bullet with a mass of $6 \mathrm{~g}$ fired at a velocity of $122 \mathrm{~m} / \mathrm{s}$ [12]. Furthermore, injury tolerance curves showed that if the mass of the bullet is increased to $140 \mathrm{~g}$ the velocity should be reduced to $18 \mathrm{~m} /$ $\mathrm{s}$ to avoid serious injuries to the chest of a female; a speed that is well below that of current "less-lethal" munitions [12].

Because of these safety concerns, rubber bullets have been replaced by plastic rounds in many countries [1-3]. The latter are more accurate and have less wounding potential $[1,3,6,8]$. Interestingly however, the reported fatality rate of plastic bullets is approximately 1:4000 bullets fired as opposed to 1:18000 for rubber bullets. Those numbers, however, may be misleading because of the many different projectiles with variable wounding power used around the world $[6,8,10,11]$. Nonetheless, similar to rubber bullets, the head and the chest are arguably the areas of the body most vulnerable to severe injuries caused by plastic rounds $[2,3,10,11,13]$.

Out of the 18 articles reviewed in this study plastic bullets were used in 11, while rubber bullets were used in 8 others; one study reported both types of ammunition. There were 4 deaths from intra-thoracic injuries caused by rubber bullets and 8 deaths from intra-thoracic injuries provoked by plastic ones [11,13-17].

With respect to intra-thoracic penetration, it was recently demonstrated in post-mortem human subjects, using a 12-gauge $(6.4 \mathrm{~g})$ rubber bullet, that the region with lowest average energy for penetration impact was the area between the ribs $\left(33.1 \mathrm{~J} / \mathrm{cm}^{2}\right)$, while the posterior rib area had the highest energy density for penetrating events $\left(55.9 \mathrm{~J} / \mathrm{cm}^{2}\right)$ [18]. Thus, based on our review, many "lesslethal" munitions have impact energy above the threshold for penetration; including the one described in the present case report $(200 \mathrm{~J})$. Therefore, it is not surprising that intra-thoracic penetration was described in more than half of the reports that were reviewed [6,13,14,16,17, 19-22]. It is interesting to note that significant injuries, such as, rib fractures, pneumothorax, hemothorax, and contusions to the heart and lung also occurred independently of intrathoracic penetration; including the death of a female patient who sustained left ventricle and pulmonary lacerations $[1-3,8,9,11,23,24]$.

In pursue of safer "less-lethal" impact munitions manufactures developed the attenuated energy projectiles (AEP). These bullets were designed to duplicate the ballistic performance of the advanced plastic baton rounds but reduce the risk of serious injury in cases of inaccurate fire [2]. These types of projectiles have a deformable head above the solid polyurethane polymer base of the standard plastic baton rounds [25]. On inadvertently hitting a hard target like the head or the chest, the AEP should deform, spreading the impact over a greater area and a longer time period, decreasing the likely hood of serious injury and penetration. Furthermore, they provide better firing accuracy than previous plastic bullets, and do not fragment reducing the risk of accidental injuries [2]. However, a recent report of 13 patients demonstrated that even attenuated energy projectiles are associated with a $37 \%$ incidence of significant injuries to the head, neck, and the chest (AIS 2-5), but there were no cases of intra-thoracic penetrating [2]. Our case apparently is the first one in which there was intra-thoracic penetration by an attenuated energy projectile.

In summary, to decrease serious injury caused by "lesslethal" impact munitions, the "rules of engagement" should be rigorously followed, even if the munition is an AEP.

\section{Conclusion}

Even though the nature of the wound caused by attenuated energy bullets is generally blunt, penetration can occur specially when fired from close range at the torso. Therefore, patients who sustain less lethal ammunition injury to the chest should be thoroughly investigated with chest radiography and CT scan regardless of the ballistic features of the projectile.

\section{Competing interests}

The authors declare that they have no competing interests.

\section{Authors' contributions}

JBRN drafted the manuscript and operated on the patient. FDFS, LBOP, and LCT have been involved in drafting the manuscript and the operation; HT, expert opinion on ballistics and revising the manuscript for important intellectual content; SBR, drafting and revising the manuscript for important intellectual content; All authors gave final approval of the version to be published. 


\section{Consent}

A written informed consent was obtained from the patient for publication of this case report and any accompanying images. A copy of the written consent is available for review by the Editor-in-Chief of this journal.

\section{Acknowledgements}

Coordenacao de Aperfeicoamento de Pessoal de Nivel Superior (CAPESBrazil) for their support.

\section{References}

I. Hughes D, Maguire K, Dunn F, Fitzpatrick S, Rocke LG: Plastic baton round injuries. Emerg Med J 2005, 22: I I I-I I 2.

2. Maguire K, Hughes DM, Fitzpatrick MS, Dunn F, Rocke LG, Baird CJ: Injuries caused by the attenuated energy projectile: the latest less lethal option. Emerg Med J 2007, 24:103-105.

3. Rocke L: Injuries caused by plastic bullets compared with those caused by rubber bullets. Lancet 1983, 8830:919-920.

4. Ackerman BT, Ho JD: Specialty munitions. In Tactical Emergency Medicine Edited by: Schwartz RB, McManus JG, Swieton RE. Philadelphia: Lippincott, Williams \& Wilkins; 2008:27-3I.

5. Sellier KG, Kneubuehl BP: Wound Ballistic and the Scientific Background Berlin: Springer; 1992.

6. Mahajna A, Aboud N, Harbaji I, Agbaria A, Lankovsky Z, Michaelson $M$, Fisher $D$, Krausz MM: Blunt and penetrating injuries caused by rubber bullets during the Israeli-Arab conflict in October, 2000: a retrospective study. Lancet 2002, 359:1795-1800.

7. Less Lethal Weapon Effectiveness Use of Force and Suspect and Officer Injuries: A Five Year Analysis. U.S. Department of Justice 2008 [http://www.ncirs.gov/pdffiles I/nii/grants/ 22408I.pdf].

8. Millar R, Rutherford WH, Johnston S, Malhotra JV: Injuries caused by rubber bullets: a report on 90 patients. Br J Surg 1975, 62:480-486.

9. Shaw J: Pulmonary contusion in children due to rubber bullet injuries. $B M]$ I 972 , 4:764-766.

10. Steele JA, McBride SJ, Kelly J, Dearden CH, Rocke LG: Plastic bullet injuries in Northern Ireland: experiences during a week of civil disturbance. J Trauma 1999, 46:7||-7|4.

II. Chute DJ, Smialek JE: Injury patterns in a plastic (AR-I) baton fatality. Am J Forensic Med Pathol 1998, 19:226-229.

12. Bir C, Viano D: Design and injury assessment criteria for blunt ballistic impacts. J Trauma 2004, 57:1218-1224.

13. Ritchie AJ: Plastic bullets: significant risk of serious injury above the diaphragm. Injury 1992, 23:265-266.

14. Chowaniec C, Kobek M, Jablonski C, Kabiesz-Nenickza S, Karczewska W: Case-study from fatal gunshot wounds from nonlethal projectiles. Forensic Sci Int 2008, I 78:213-2I7.

15. Ritchie AJ, Gibbons JRP: Plastic bullets in Northern Ireland. BMJ 1990, 301:1332.

16. Voiglio EJ, Fanton L, Caillot JL, Neidhardt JPH, Malicier D: Suicide with non-lethal firearm. Lancet 1998, 353:882.

17. Yellin A, Golan M, Klein E, Avigad I, Rosenman J, Lieberman Y: Penetrating thoracic wounds caused by plastic bullets. I Thorac Cardiovasc Surg 1992, 103:381-385.

18. Bir CA, Stewart S], Wilhelm M: Skin penetration assessment of less lethal kinetic energy munitions. J Forensic Sci 2005, 50: I-4.

19. Hiss J, Hellman FN: Plastic and rubber ammunition lethal injuries: the Israel experience. Med Sci Law 1997, 37:139-144.

20. Kalebi A, Olumbe AKO: Death following rubber bullet wounds to the chest. East Afr Med J 2005, 82:382-384.

21. Missliwetz J, Lindermann A: Gunshot wounds caused by Fiocchi anticrime cartridges (plastic bullets). Am J Forensic Med Pathol | 991, I 2:209-2 I2

22. Walden R, Lynn M, Golan M, Garniek A: Plastic bullet arterial embolization following gunshot injury to the heart. Case report and review of the literature. J Cardiovasc Surg (Torino) 1990, 31:482-485.

23. Wahl P, Schreyer N, Yersin B: Injury patterns of the Flash Ball ${ }^{\circledR}$, a less-lethal weapon used for law enforcement: report of two cases and review of the literature. J Emerg Med 2006, 3I:325-330.
24. Sheridan SM, Whitlock RIH: Plastic baton rounds. Br J Oral Surg 1983, $21: 259-267$.

25. Jane's Defence.37mmL60AIAEP Impact Round (United Kingdom), Riot Control Ammunition. .
Publish with Bio Med Central and every scientist can read your work free of charge

"BioMed Central will be the most significant development for disseminating the results of biomedical research in our lifetime. "

Sir Paul Nurse, Cancer Research UK

Your research papers will be:

- available free of charge to the entire biomedical community

- peer reviewed and published immediately upon acceptance

- cited in PubMed and archived on PubMed Central

- yours - you keep the copyright
BioMedcentral 